
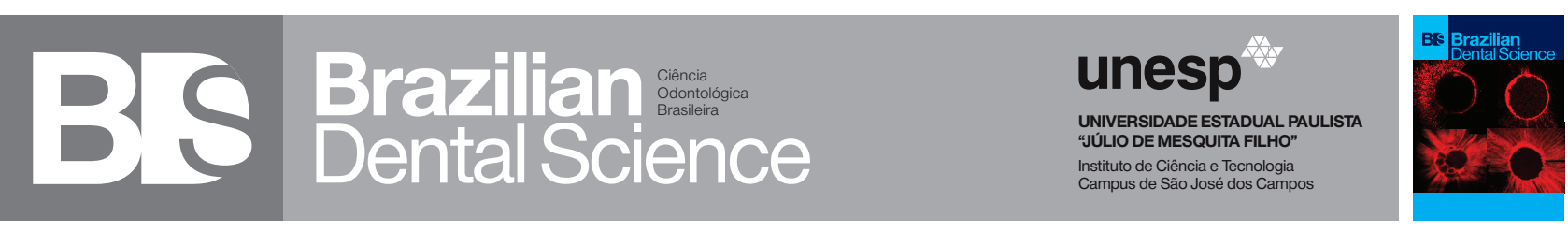

\title{
Effect of Surface Treatment of Two Ceramic Materials by Er,Cr:YSGG Laser Irradiation on The Shear Bond Strength to Resin Cement: "a Comparative in-Vitro Study"
}

Efeito do tratamento de superfície de dois materiais cerâmicos por Irradiação de laser Er,Cr:YSGG na resistência ao cisalhamento a cimento Resinoso: "um estudo comparativo in-Vitro"

Shahd T. MANDIL ${ }^{1}$, Hesham KATAMISH ${ }^{2}$, Tarek SALAH ${ }^{3}$

1 - Faculty of Dentistry - Misr International University - Cairo - Egypt.

2 - Department of Fixed Prosthodontics - Faculty of Oral and Dental Medicine - Cairo University - Giza - Egypt.

3 - Department of Fixed Prosthodontics - Faculty of Oral and Dental Medicine - Ain Shams University - Cairo - Egypt.

\section{ABSTRACT}

Objective: The aim of this study is to assess the effect of Er,Cr:YSGG laser on the shear bond strength (SBS) and surface topography of two $\mathrm{CAD} / \mathrm{CAM}$ ceramic materials bonded with selfadhesive resin cement. Material and methods: sixty ceramic CAD/CAM discs were obtained, 30 lithium disilicate (IPS Emax) (Group LD), and 30 hybrid resin ceramic (Vita Enamic) (Group RC). The Slices were allocated into six groups $(n=10)$ according to ceramic material and surface treatment; Group (LD-C): IPS Emax treated with 9\% hydrofluoric acid (HF), Groups (LD-L1) and (LD-L2): IPS Emax treated with Er,Cr:YSGG, Group (RC-C): Vita Enamic treated with 9\% hydrofluoric acid (HF), Groups (RC-L1) and (RC-L2): Vita Enamic treated with Er,Cr:YSGG laser. The laser parameters and irradiation protocol was $1.5 \mathrm{~W}$ (L1) and $2.5 \mathrm{~W}$ (L2). All samples were cemented with self-adhesive resin cement and thermocycled for 5000 cycles. The SBS was measured using a universal testing machine and the mean values $(\mathrm{MPa})$ were analyzed using Two-way (ANOVA) $(\mathrm{P} \leq 0.05)$ and Bonferroni's post-hoc test. Results: RC-C (16.55) showed highest SBS followed by LD-C (13.79), which revealed no statistically significant difference with RCP1 (12.33) and RC-P2 (11.2). The lowest SBS values were found with LD-P1 (2.7) and LDP2 (2.1). SEM analysis revealed Vita Enamic to

\section{RESUMO}

Objetivo: O objetivo deste estudo é avaliar o efeito do laser Er,Cr:YSGG naresistência ao cisalhamento (SBS) e na topografia superficial de dois materiaiscerâmicos CAD/CAM cimentados com cimento resinoso autoadesivo. Material e métodos: foram obtidos sessenta discos cerâmicos CAD/CAM, 30 dedissilicato de lítio (IPS Emax) (Grupo LD) e 30 de resina híbrida (Vita Enamic) (Grupo RC). Os discos foram alocados em seis grupos $(n=10)$, de acordo como material cerâmico e o tratamento de superfície; Grupo (LD-C): IPS Emaxtratado com ácido fluorídrico (HF) a 9\%, Grupos (LD-L1) e (LD-L2): IPS Emaxtratado com Er,Cr:YSGG, Grupo (RC-C): Vita Enamic tratada com ácidofluorídrico (HF) a 9\%, Grupos (RC-L1) e (RC-L2): Vita Enamic tratada comlaser Er,Cr:YSGG. Os parâmetros do laser e o protocolo de irradiação foram de1,5 W (L1) e 2,5 W (L2). Todas as amostras foram cimentadas com cimentoresinoso autoadesivo e termocicladas por 5000 ciclos. A SBS foi medida usando uma máquina de ensaios universais e os valores médios (MPa) foram analisadosusando (ANOVA) a dois fatores $(P \leq 0,05)$ e teste post-hoc deBonferroni. Resultados: RC-C $(16,55)$ apresentou maior SBS seguido por $\mathrm{LD}-\mathrm{C}(13,79)$, que não revelou diferença estatisticamente significante com RCP1 $(12,33)$ e RC-P2 $(11,2)$. Os menores valores de SBS foram encontrados comLD-P1 (2,7) e LD-P2 $(2,1)$. A análise por MEV revelou que a Vita Enamic possuimaior rugosidade de superfície. A análise do 
have the highest surface roughness. Fracture pattern analysis showed adhesive failure with IPS Emax groups and mixed failure with Vita Enamic groups. Conclusion: Er,Cr:YSGG laser irradiation with the parameters used did not increase SBS of IPS Emax and Vita Enamic with composite resin compared to HF acid etching.

\section{KEYWORDS}

Er,Cr:YSGG laser; Shear bond strength; Surface treatment; Ceramic materials. padrão de fratura mostrou falhaadesiva nos grupos IPS Emax e falha mista nos grupos Vita Enamic. Conclusão: A irradiação com laser Er,Cr:YSGG com os parâmetros utilizadosnão aumentou a SBS de IPS Emax e Vita Enamic ao cimento resinoso emcomparação com o condicionamento ácido com HF.

\section{PALAVRAS-CHAVE}

LaserdeEr,Cr:YSGG; Resistência ao cisalhamento; Tratamento de superfície; Materiais cerâmicos.

\section{INTRODUCTION}

$\mathrm{D}$ ue to advancements in material formulations and manufacturing technologies, many clinicians opt for ceramic restorations for the majority of prosthetic cases 1-3]. Unfortunately, chipping and/or fracture are commonly frequented problems associated with ceramic restorations both monolithic and bilayered [4,5]. Due to the high cost of restoration replacement, intra oral repair with composite resin is suggested. Intraoral repair, compared to remake, not only saves time and expenses for patient and operator alike, but is also not traumatic to the involved teeth and surrounding tissues [6-8].

The concept of intraoral repair of ceramic restorations using composite resin is viable through proper surface treatment of the defective area [9]. Etching of the ceramic restorations with 5-9\% Hydrofluoric acid (HF) has been proven as the most effective, by increasing the etched ceramic surface's surface roughness as well as its surface energy, creating favorable substrate for micromechanical bonding with composite resin [1012]. However, intraorally, HF acid has been proven to pose serious health hazards for both patient and clinician [13-15]. A study by Ozcan $\mathrm{M}$ et al., revealed that HF acid, upon contact and/or inhalation, has the ability to cause skin and/or nail burn, eye irritation, severe nose and throat irritation, as well lung damage and poisoning [16].

With the introduction of erbium lasers Er:YAG (Erbium: Yttrium Aluminium Garnet) $(2.94 \mu \mathrm{m})$ and Er,Cr:YSGG (Erbium, Chromium: Yttrium Scandium Gallium Garnet) $(2.78 \mu \mathrm{m})$ into dentistry, their use has been proposed for intraoral surface treatment of ceramic restorations as easier, safer and more ergonomic options [17]. Erbium lasers are considered dental hard tissue lasers, which work by targeting the water content, resulting in micro-explosions of the surface [18].

According to the related literature, some studies found erbium lasers effective in increasing roughness of ceramic surfaces [19-22] which can theoretically enhance the bond strength with repairing composite resin [10,23-25]. However, other studies found erbium laser surface treatment to result in no increase or even diminished bond strength $[26,27]$.

Regarding CAD/CAM hybrid resin ceramics, studies were published on the impact of different surface treatments of indirect restorations on its bond strength to resin cement [29-30]. Recently, Erbium lasers have been established efficacious on composite resin restorations such as composite inlays, onlays, etc... as surface treatment for enhancing bond strength [31-34]. On the contrary, the efficacy of Er,Cr:YSGG laser irradiation on hybrid resin ceramics is yet to be proven due to the 
shortage of related studies [35].

The proper power settings of Er,Cr:YSGG laser in producing surface roughness to glass ceramics and composite materials are still questionable. Thus, the aim of this study was to test the effect of Er,Cr:YSGG laser on lithium disilicate and hybrid ceramics compared to hydrofluoric acid etching as alternative surface treatment on the shear bond strength to resin cement. This study tested the null hypothesis that ceramic surface treatment with Er,Cr:YSGG laser irradiation will have no effect on the shear bond strength to resin cement.

\section{MATERIALS AND METHODS}

\section{Sample preparation}

A total of 10 blocks of two different ceramic materials IPS Emax CAD (Ivoclar Vivadent AG, Schaan, Liechtenstein) and Vita Enamic (VITA Zahnfabrik, Germany) were used. A microtome sectioning device (IsoMet precision cutting micro-saw, Buehler, USA) was used for sectioning the ceramic blocks by slow speed diamond saw under water cooling to obtain a standardized $(2 \mathrm{~mm})$ thick slices as recommended by previous studies26,35. Sixty $2 \mathrm{~mm}$ thick slices were obtained; 30 slices of partially crystallized lithium disilicate IPS Emax CAD and 30 slices of hybrid resin ceramic Vita Enamic. The IPS Emax slices were fired in a press/firing furnace (Programat P300,Ivoclar vivadent, AG Schaan, Liechtenstein) for 25-30 min at $840{ }^{\circ} \mathrm{C}$. Then all slices were wet ground on one side with 600 grit silicon carbide paper for smoothness $[26,35]$ then all slices were placed in an ultrasonic cleaner for $180 \mathrm{~s}$ to remove surface residuals and contaminants.

\section{Surface treatment}

The samples were then randomly divided into 6 groups $(\mathrm{n}=10)$ according to the ceramic surface treatment used. The adhesive systems used in this study are listed in table I.

Group (LD-C) - ( control group) IPS
Emax slices were treated with 9.5\% HF acid (buffered porcelain Etch; Ultradent products, South Jordan, UT, USA) on all surface for 20 $s$ as per manufacturer's instructions. Then rinsed with air/water spray for another $20 \mathrm{~s}$ and dried.

Groups (LD-L1 and LD-L2) - IPS Emax slices were subjected to Er,Cr:YSGG laser irradiation (WATERLASE® IPLUS; Biolase Technology Inc., Irvine, CA ) at $2.78 \mu \mathrm{m}$ wavelength with a pulse duration of 140 $200 \mu \mathrm{s}$ and a repetition rate of $10 \mathrm{~Hz}$. Two different power settings were used, $1.5 \mathrm{~W}$ and $2.5 \mathrm{~W}$, respectively with a fixed energy parameter of $200 \mathrm{~mJ}$ energy at $71 \mathrm{~J} / \mathrm{cm} 2$ energy density as described in previous studies [26]. An optical gold fiber tip (MZ8) of $800 \mu \mathrm{m}$ diameter and $6 \mathrm{~mm}$ length was held manually by trained practitioner to be perpendicular and at approximately $1 \mathrm{~mm}$ away from the sample surface [36]. The laser scanning was performed under air/water cooling (50\% air and $50 \%$ water) in a sweeping movement over the entire surface for $60 \mathrm{~s}$. All samples were then rinsed under distilled water to remove surface residuals and dried.

Group (RC-C) - ( control group) Vita Enamic slices were treated using 9.5\% HF acid (buffered porcelain Etch; Ultradent products, South Jordan, UT, USA) for $60 \mathrm{~s}$ with the same manner as explained in group (LD-C).

Groups (RC-L1 and RC-L2) -- Vita Enamic slices were subjected to Er,Cr:YSGG laser irradiation (WATERLASE $\AA$ IPLUS; Biolase Technology Inc., Irvine, CA) at 2.78 $\mu \mathrm{m}$ wavelength for $20 \mathrm{~s}$ [35] with the same laser parameters and irradiation protocol was descried in groups (LD-L1 and LD-L2).

\section{Adhesive and restorative procedures}

As for the adhesive stage, silane (Porcelain Silane; Ultradent Product, Inc. South Jordan, UT, USA ) was applied all over dried sample surfaces for $60 \mathrm{~s}$ [37]. Plastic Tygon tubes of $2 \mathrm{~mm}$ internal diameter and 2 $\mathrm{mm}$ height were placed in the center of each 
slice for standardization. After that, the dualcured self-adhesive resin cement (DuoCem ${ }^{\circledR}$ TransRefill, Coltene, Altstätten, Switzerland) was injected using the accompanying mixing tips inside the Tygon tube till the mold was completely filled and light cured using $650 \mathrm{~mW} / \mathrm{cm} 2$ LED light cure unit (LED-D, Woodpecker, Guilin, China) for 20 s [3840]. Then after gentle removal of the Tygon tubes using a scalpel, all samples were light cured once again for $20 \mathrm{~s}$ to ensure complete polymerization.

\section{Ageing process}

All samples were submitted in a thermocycling device (Julabo GmbH, FT 200, Seelbach, Germany) for 5000 cycles between temperatures $5{ }^{\circ} \mathrm{C}$ and $55{ }^{\circ} \mathrm{C}$, to simulate the thermal changes inside oral cavity during clinical service [41].

\section{Shear bond strength (SBS) test}

The samples were mounted in acrylic resin molds to be secured into a computerized universal testing machine (Instron, Norwood, MA, USA) for testing the macro shear bond strength of the adhesive interface between the ceramic disc and the resin cement $[42,43]$.

Each sample was subjected to a shearing force by a uni-beveled chisel of crosshead speed of $0.5 \mathrm{~mm} / \mathrm{min}$ and a load cell of 500 $\mathrm{N}$ until fracture. The shear bond strength was computed form the highest point on the stress-strain curve (maximum stress) that was measured by the load cell of the testing machine. The final results were expressed in Megapascals (MPa). (SEM)

Scanning electron microscope analysis

Twelve additional samples one from each group were specially prepared for surface topography analysis using scanning electron microscope (SEM). Six samples one from each group was subjected to surface treatment only and the other 6 fractured samples after shear bond strength testing. All samples were sputter coated with gold by a gold sputter device (Emitech/ Quorum sputter coater K500X, England). All the gold-sputtered samples were scanned under a scanning electron microscope (Quanta 250 FEG, FEI Co., Netherlands) with an accelerating voltage of $30 \mathrm{~K} . \mathrm{V}$ and a magnification of 5000X. The software ImageJ (ImageJ 1.52k, Wayne Rasband, NIH, USA) was used for SEM images analysis.

\section{Failure mode analysis}

All fractured samples were observed under stereomicroscope (Nikon, SMZ1500, America) at 40x magnification for fracture patterns determination (adhesive- Type I, cohesive- Type II or mixed- Type III) $[44,45]$.

\section{Statistical analysis}

Numerical data were explored for normality by checking the distribution of data and using tests of normality (KolmogorovSmirnov and Shapiro-Wilk tests). Shear bond strength data showed normal (parametric) distribution. Parametric data were presented as mean and standard deviation (SD) values. Two-way ANOVA test was used to study the effect of ceramic type, surface treatment and the interaction between the two variables on mean shear bond strength. Bonferroni's posthoc test was used for pair-wise comparisons. The significance level was set at $\mathrm{P} \leq 0.05$. Statistical analysis was performed with IBM SPSS Statistics for Windows, Version 22.0. Armonk, NY: IBM Corp.

\section{RESULTS}

\section{Comparison between ceramic types}

With acid etch, there was no statistically significant difference between mean shear bond strength of the two ceramic types $(\mathrm{P}$-value $=0.076$, Effect size $=0.047)$.

While with Laser $1.5 \mathrm{~W}$ as well as Laser $2.5 \mathrm{~W}$; IPS E.max showed statistically significantly lower mean shear bond strength 
than Vita Enamic (P-value $<0.001$, Effect size $=0.375)$ and $($ P-value $<0.001$, Effect size $=$ 0.349), respectively.

\section{Comparison between surface treatments}

Whether with IPS E.max or Vita Enamic; there was a statistically significant difference between surface treatments (P-value < 0.001 , Effect size $=0.529$ and P-value $=$ 0.002 , Effect size $=0.170$ respectively). Pair-wise comparisons between the surfaces treatments revealed that acid etch recorded the statistically significantly highest mean shear bond strength. There was no statistically significant difference between Laser $1.5 \mathrm{~W}$ and Laser $2.5 \mathrm{~W}$; both showed the statistically significantly lowest mean values (P-value....).

All results are listed in Table I and presented in Figure 1.

Table I - The mean, standard deviation (SD) values and results of two-way ANOVA test for comparison between shear bond strength of the different interactions of variables

\begin{tabular}{|c|c|c|c|c|c|c|}
\hline \multirow{2}{*}{$\begin{array}{l}\text { Surface } \\
\text { Treatment }\end{array}$} & \multicolumn{2}{|c|}{$\begin{array}{l}\text { IPSE.max } \\
\text { (LD) }\end{array}$} & \multicolumn{2}{|c|}{$\begin{array}{l}\text { Vita Enamic } \\
\text { (RC) }\end{array}$} & \multirow{2}{*}{$\begin{array}{c}P \text {-value } \\
\text { (Between } \\
\text { ceramic } \\
\text { type) }\end{array}$} & \multirow{2}{*}{$\begin{array}{c}\text { Effect Size } \\
\text { (Partialeta } \\
\text { squared) }\end{array}$} \\
\hline & Mean & SD & Mean & SD & & \\
\hline Acid Etch (C) & $13.79^{\mathrm{A}}$ & 3.78 & $16.55^{\mathrm{A}}$ & 5 & 0.076 & 0.047 \\
\hline $\begin{array}{l}\text { Laser 1.5W } \\
\text { (L1) }\end{array}$ & $2.7^{\mathrm{B}}$ & 0.9 & $12.33^{\text {B }}$ & 4.7 & $<0.001^{*}$ & 0.375 \\
\hline $\begin{array}{l}\text { Laser 2.5W } \\
\text { (L2) }\end{array}$ & $2.1^{\mathrm{B}}$ & 0.85 & $11.2^{\mathrm{B}}$ & 3.31 & $<0.001^{*}$ & 0.349 \\
\hline $\begin{array}{l}P \text {-value (Be- } \\
\text { tween surface } \\
\text { treatments) }\end{array}$ & \multicolumn{2}{|c|}{$<0.001^{*}$} & \multicolumn{2}{|c|}{$0.002^{*}$} & & \\
\hline $\begin{array}{l}\text { Effect size } \\
\text { (Partial eta } \\
\text { squared) }\end{array}$ & \multicolumn{2}{|c|}{0.529} & \multicolumn{2}{|c|}{0.170} & & \\
\hline
\end{tabular}
(SEM)

\section{Scanning electron microscope analysis}

The groups were analyzed after the designated treatment and after SBS testing. IPS Emax samples were depicted in Figures 3-5, while the Vita Enamic samples were depicted in
Figures 6-8.

\section{Failure analysis}

For the failure mode in all experimental groups, it was predominantly mixed failure (type III) in (LD-C) and predominantly adhesive failure (type I) of the adhesive interface in (LDP1 and LD-P2) [44,45]. On the contrary, the failure pattern was mainly cohesive (type II) of the substrate (ceramic) for (RC-C), but there were approximately equal mixed and cohesive failures of the substrate (ceramic) for (RC-P1 and RC-P2). As shown in Figure 2.

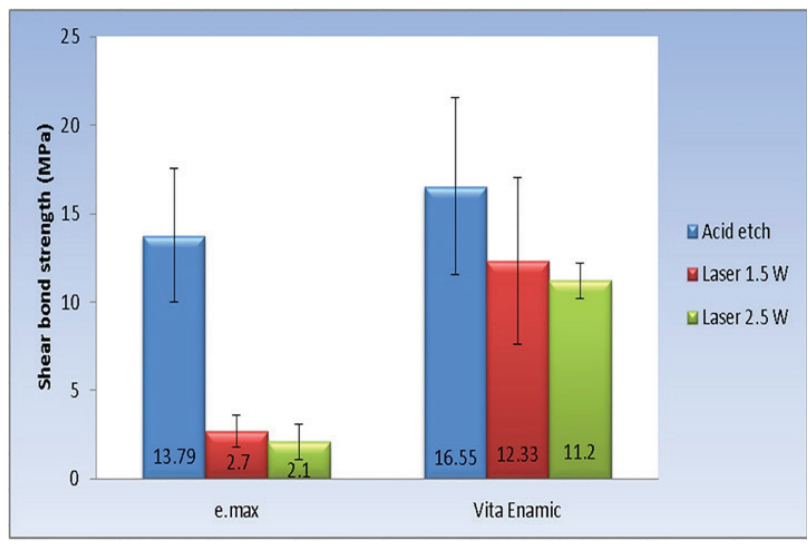

Figure 1- Bar chart representing mean and standard deviation values for shear bond strength of different interactions of variables.

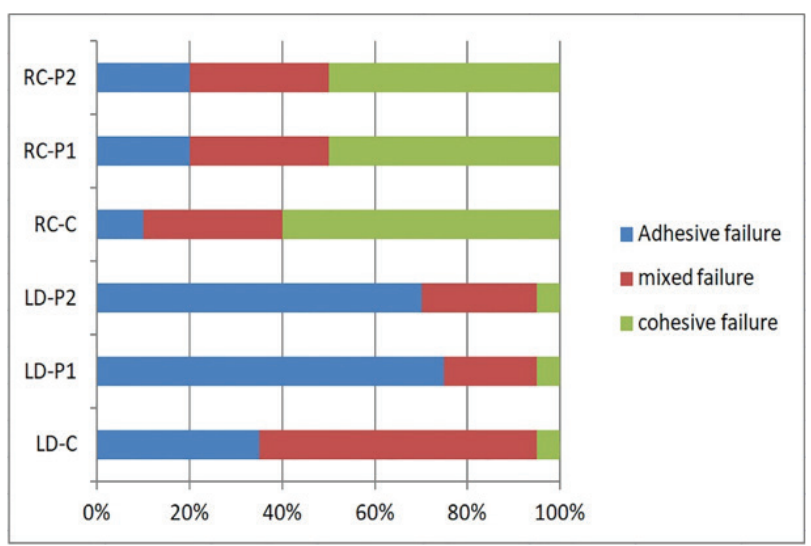

Figure 2 - Bar chart representing the mode of failure of all groups after SBS test. Failure mode determinations: Type I: adhesive failure at the adhesive bond; Type II: cohesive failure of the ceramic substrate or resin cement: complete fracture of the substrate or resin; Type III: mixed failure: both adhesive and cohesive failures. 


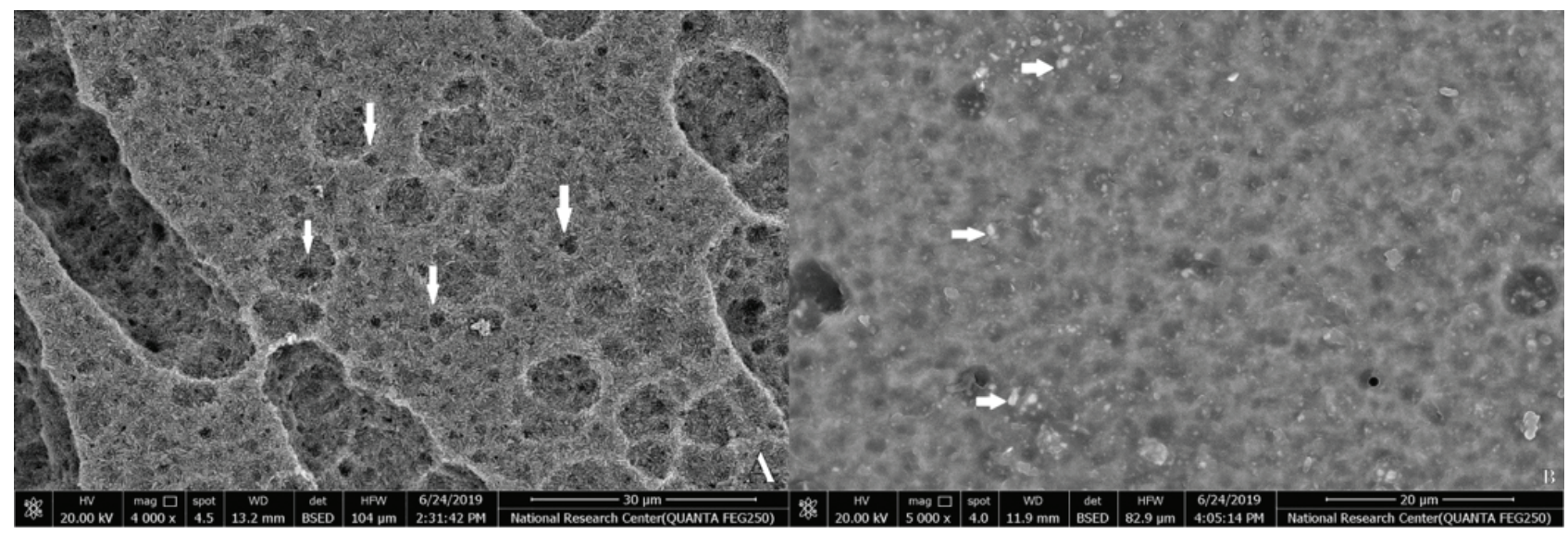

Figure 3 - SEM micrograph 4000x of group LD-C HF acid; A: Numerous micropores could be seen white arrows, b: after SBS test. Resin remnants are shown on the specimen with visible filler particles white arrows.

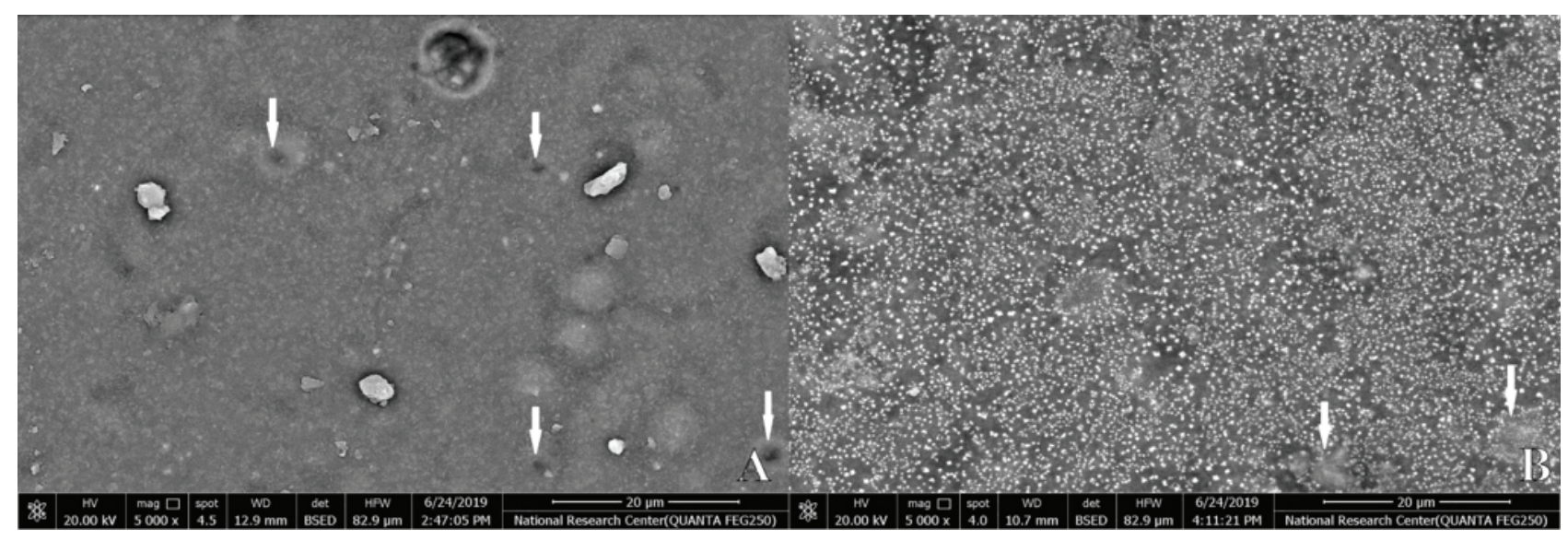

Figure 4 - SEM micrograph 5000x of group LD-L11.5 W; A: Minimal pore formation could be seen. Few micropores are seen white arrows, B: after SBS test. Resin remnants shown white arrows.

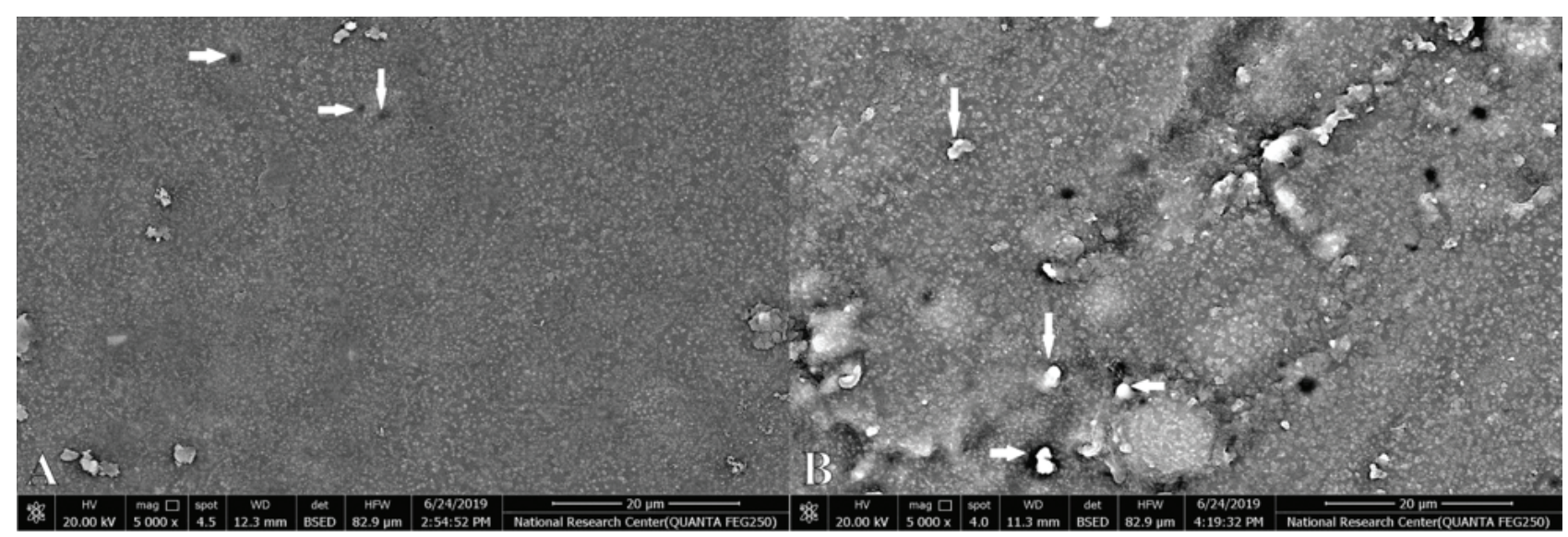

Figure 5 - SEM micrograph 5000x of group LD-L2 2.5 W; A: Minimal number of micro pores white arrows, B: after SBS test. Resin remnants are shown throughout the surface. 


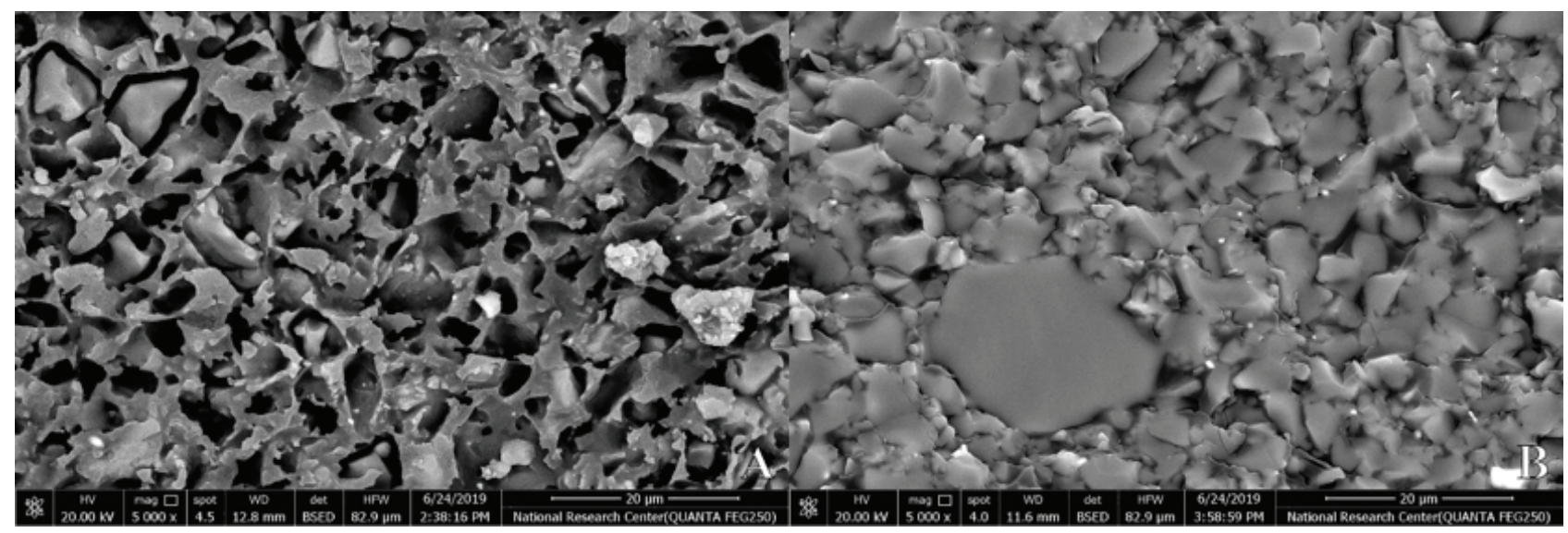

Figure 6 - SEM micrograph 5000x of group RC-C HF acid; A: High micropore formation giving a honey comb appearance, B: after SBS test, pores filled with resin.

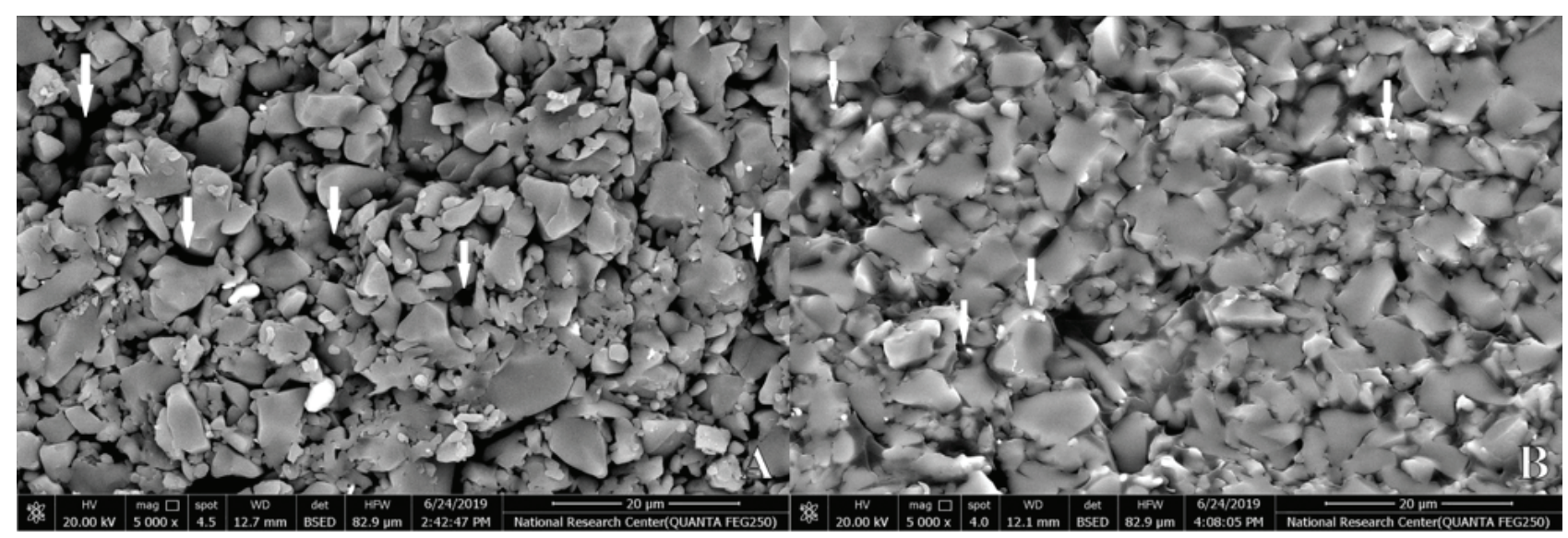

Figure 7 - SEM micrograph 5000x of group RC-P11.5 W; A: Lased enamic showing a different pattern of micropore formation white arrows. B: after SBS test, collapsed grains with resin remnants are seen white arrows.

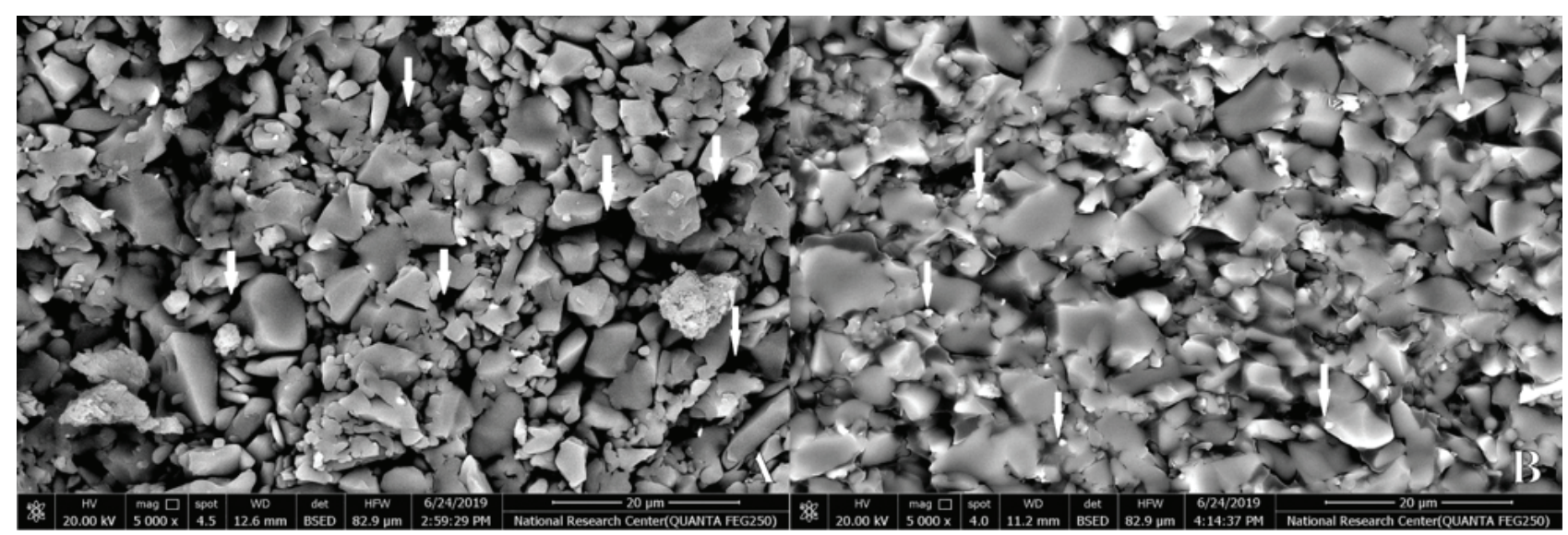

Figure 8 - SEM micrograph 5000x of group RC-P2 2.5 W; A: lased enamic showing similar pattern of micropore formation to that of RC-P1, B: after SBS test collapsed grains with resin remnants. 


\section{DISCUSSION}

In the current study the shear bond strength (SBS) between of IPS Emax CAD and Vita Enamic ceramic restorations to resin cement was tested after HF acid etching and 2 different laser parameters by Er,Cr:YSGG laser irradiation were applied.

Due to the nature of the data, the null hypothesis that ceramic surface treatment with Er,Cr:YSGG laser irradiation with the parameters used will have no effect on lithium disilicate and resin ceramics regarding the (SBS) was accepted. There was no statistically significant difference between Laser $1.5 \mathrm{~W}$ and Laser $2.5 \mathrm{~W}$ with the two ceramic materials used; both showed statistically significantly lowest mean values in comparison to HF acid etched control group. Group LD-C (13.79 $\mathrm{MPa} \pm$ 3.78) showed statistically significant higher SBS than both LD-P1 (2.7 MPa \pm 0.9 ) and LD-P2 (2.1 MPa \pm 0.85$)$ where (P-value < 0.001).

These results are in agreement with those of Chaharom et al, in which the Er,Cr:YSGG laser surface treatment $(1.5 \mathrm{~W}$ and $6 \mathrm{~W})$ revealed no significant difference to $\mathrm{HF}$ acid etching regarding bond strength [27]. Another study by Kursoglu et al. found that the SBS value was the highest with acid etching group while the Er,Cr:YSGG laser treatment (1.5 and $2.5 \mathrm{~W}$ ) significantly increased the bond strength with resin cement compared to the untreated group. It seems that higher power of laser irradiation how the $6 \mathrm{~W}$ Er,Cr:YSGG laser irradiation led to weakening and over destruction of the surface that decreased the bond strength [26].

On the other hand, a study by Kara HB et al. found no difference between Er:YAG laser irradiation and HF acid etching on surface roughness of lithium disilicate [21]. Moreover, Dilber et al. stated that Er:YAG laser irradiation produces higher surface roughness than HF acid etching on lithium disilicate [20]. Yassaei et al. published that Er;YAG at 1.6 W had higher bond strength than HF acid etching [24]. Likewise, Ozdemir $\mathrm{H}$ et al. and Alakus-sabuncoglu et al. agreed that Er:YAG laser irradiation increased the SBS values and may be used as alternative to $\mathrm{HF}$ acid etching. However, the appropriate laser parameters needs more studies [25].

For more clinically relevant results, all bonded samples were submitted to a thermocycling aging process to simulate the deteriorating effects on the bond strength throughout clinical service [41]. Yet, a recent literature about thermal cycling in in-vitro studies stated that still no actual number of cycles was truly proposed to correspond to the actual time of clinical service [46].

According to previous related studies [47], laser output power in the range of $1 \mathrm{~W}-3 \mathrm{~W}$ resulted in the most favorable ceramic surface topography. Increasing the power settings, conversely, resulted in overdue melting and overdestruction of the ceramic surface [26]. This leads to decreased bond strength values despite some authors finding higher resin penetration with high power settings owing to its high destructive effect. Some studies reported erosion of the ceramic surface with laser powers of $10 \mathrm{~W}$ that may weakens the ceramic surface [23]. The mean value of the bond strength of group LD-C in the present study was higher than the bond strength values of Korsuglu et al. and Chaharom et al. (8.42 MPa) and (10.32 MPa), respectively, which may be explained due to variations in etching and bonding systems used [26,27].

The SEM analysis of group LD-C images corresponds with the SBS values, Figure 3 (A) revealed surface irregularities with micropores formation as seen with typical etched ceramic surfaces. Figure 3 (B) shows resin clogged microporosities. On the other hand, the SEM images of the LD-L1 and LD-L2 groups, Figures 4 (A) and 5 (A) showed rather moderate irregularities with mostly a smooth surface while resin remnants were found in Figures 4 (B) and 5 (B). Likewise, the failure mode analysis showed mixed failure of adhesive and cohesive failure of the bond interface and the resin cement of group LD-C, denoting strong micromechanical bond formation. Conversely, it was mostly adhesive failure by separation of the bond interface for $\mathrm{LD}$ - 
L1 and LD-L2 groups, which may be explained by the weak micromechanical bond formed between two materials, as represented in Figure 2.

Concerning the results of the Vita Enamic groups, HF acid etching significantly increased the shear bond strength with resin cement; group RC-C (16.55 $\pm 5 \mathrm{MPa})$ resulted in the highest bond strength value in comparison to group RCL1 (12.33 $\pm 4.7 \mathrm{MPa})$ and group RC-L2 (11.2 \pm $3.31 \mathrm{MPa})$ where $(\mathrm{P}$-value $=0.002)$. These results corroborate with that of Barutcigil et al, found that HF acid etching $(10.14 \pm 2.51 \mathrm{MPa})$ revealed higher SBS values compared to $2 \mathrm{~W}$ Er,Cr:YSGG laser $(9.13 \pm 2.64 \mathrm{MPa})$ on Vita Enamic which is not significantly different [35]. The author also, tested that $2 \mathrm{~W}$ Er,Cr:YSGG laser irradiation group had the same SBS value as with the sandblasting group [35]. From previous literatures, Mirazaie $\mathrm{M}$ et al. studied the effects of Er,Cr:YSGG laser treatment of microhybrid composite on bond strength with different laser parameters $(2,3$ and $4 \mathrm{~W}$ ) and published that $3 \mathrm{~W}$ can be used as alternative surface treatment technique for composite resin [32]. F D Oz et al. also studied the repair bond strength of resin composite to two different hybrid CAD/CAM ceramic blocks after surface treatment with six different methods and found that $3 \mathrm{~W}$ Er,Cr:YSGG laser had highest SBS value [48]. Moreover, a recent study [35] compared different Er,Cr:YSGG laser power settings on composite resin and found no determined difference between (1.5, 2 and $3 \mathrm{~W}$ ) for surface roughness. Kimyai et al. claimed that 2 W Er,Cr:YSGG laser irradiation can enhance bond strength after comparing three different surface treatment methods; $2 \mathrm{~W}$ Er,Cr:YSGG, diamond bur application and air abrasion on the repair bond strength with composite resin [31]. The HF acid partially dissolves the resin matrix to expose filler particles for micro-mechanical bonding with resin-based materials [49], and most probably that the ablation process of Er,Cr:YSGG laser irradiation targets the resin matrix of hybrid ceramics and expose the filler particles to bond with resin cement [35].

The Er,Cr:YSGG laser have been introduced into restorative dentistry owing to its capabilities in surface roughness of different dental materials to enhance the bond strength $[26,27,33-35]$, the SEM images of the hybrid resin ceramic showed that acid etching exposed filler particles to form irregular surface with retentive micropores that may improve the mechanical interlocking with resin cement [50] as shown in Figure 6 (A) and in Figure 6 (B) the grains appeared more collapsed and the micropores completely clogged with resin. The SEM images of RC-L1 and RCL2 groups revealed moderate irregularities and micropores which may explain the lower SBS values compared with acid etching as shown in Figures 7 (A) and 8 (A), although previous literatures established that high surface roughness is not an indication of high bond strength [51]. As for Figures 7 (B) and 8 (B), grains were collapsed and most of the micropores were resin clogged.

For the failure mode analysis, group RC-C was mainly cohesive failure in the substrate and for groups RC-L1 and RC-L2 showed cohesive, mixed and adhesive failures, denoting stronger micromechanical bond between Vita Enamic and resin cement.

By comparing the SEM images between the two materials used, it was clear that Er,Cr:YSGG laser gives more favorable surface topography on hybrid resin ceramics compared to lithium disilicate, which may indicate that Er,Cr:YSGG works better with resin containing ceramics.

As for the choice of resin cement, Fuentes et al, stated that selection of the appropriate adhesive cement has higher effect on bond strength than the surface treatment used52.

The current authors chose to test the SBS as It has been known as the easiest and fastest test that allows even stress distribution during loading with more reliable results compared to micro tensile bond strength (mTBS) $[42,43]$. An adhesion area of $2 \mathrm{~mm}$ was chosen to ensure direct loading of shear stress on the bonded interface. Moreover, it was remarked by a systematic review that increasing the surface area will decrease the bond strength values [53].

The results of this study denote that Er,Cr:YSGG laser irradiation can be used easily as 
intraoral surface treatment of ceramic materials specifically with hybrid resin ceramic restorations but still there is debate about the appropriate laser parameters for more effective results.

Since Vita Enamic restorations revealed favorable adhesive results after Er,Cr:YSGG laser irradiation, this technique has the potential to provide a more favourable alternative to intraoral acid etching for restoration repair. Compared to $\mathrm{HF}$ acid etching, the laser could provide not only a cost-effective method, but also a safer hazardfree option.

The findings of the current study also presented that Er,Cr:YSGG laser surface treatment has better adhesive results with hybrid resin ceramics than glass ceramic restorations. Testing with other types of hybrid ceramics is encouraged in future studies to further analyze the potential of hard lasers on different ceramic compositions.

As this is an in vitro study, some limitations exist; only one laser type was used in the study, so further studies with different laser types should be attempted. Also, only two Er,Cr:YSGG laser parameters were used, thus, more studies are required with different parameters and different etching protocols.

\section{CONCLUSIONS}

Within the limitations of the study and the parameters used, the following could be concluded:

- The Er,Cr:YSGG laser irradiation with 1.5 $\mathrm{W}$ and $2.5 \mathrm{~W}$ parameters are not effective to be used as surface treatment method on IPS E max to enhance shear bond strength;

- Er,Cr:YSGG laser had high shear bond strength values on Vita Enamic but not as HFA etching;

- The SEM images of Er,Cr:YSGG laser irradiated Vita Enamic groups revealed surface irregularities which may enhance the micromechanical shear bond strength;

- There was no difference between $1.5 \mathrm{~W}$ and 2.5 W Er,Cr:YSGG laser irradiation on both materials.

\section{DISCLOSURE}

No conflicts of interest.

\section{REFERENCES}

1. Kelly JR ZY. Dental Ceramics for Restoration and Metal Veneering. DentClin North Am 2018;61:797-819. doi:10.1016/j.cden.2017.06.005.

2. Daou EE. Esthetic Prosthetic Restorations : Reliability and Effects onAntagonist Dentition 2015:473-81.

3. Silva LHDA, Lima E de, Miranda RB DE P, Favero SS, Lohbaueru, Cesar PF.Dental ceramics: a review of new materials andprocessing methods. Brazilian Oral Res 2017;31.

4. Thompson, V P.Rekow ED, Silva NR, Coelho PG, Zhang Y GP.Performance of Dental Ceramics : Challenges for Improvements2011:937-52 doi:10.1177/0022034510391795.

5. Lima E De, Barbosa J, Meira C, Özcan M, Cesar PF, Cesar PF. Chippingof Veneering Ceramics in Zirconium Dioxide Fixed Dental Prosthesis2015:169-73. doi:10.1007/s40496-015-0066-7.

6. Elsaka SE. Repair bond strength of resin composite to a novel CAD /CAM hybrid ceramic using different repair systems 2015;34:161-7.doi:10.4012/ dmi.2014-159.

7. Neis CA, Luísa N, Albuquerque G, Souza IDe. Surface Treatments forRepair of Feldspathic , Leucite- and Lithium Disilicate-Reinforced Glass2015;26:152-5.

8. Loomans B, Ozcan M. Intraoral Repair of Direct and Indirect Restorations:Procedures and Guidelines. Oper Dent 2016;41:S68-78. doi:10.2341/15-269-LIT.

9. Kimmich M, Stappert C. Intraoral treatment of veneering porcelainchipping of fixed dental restorations: A review and clinical application. JAm Dent Assoc 2013;144:31-44. doi:10.14219/jada.archive.2013.0011.

10. Akyil MS, Yilmaz A, Karaalioglu OF, Duymus ZY. Shear bond strength ofrepair composite resin to an acid-etched and a laser-irradiated feldspathicceramic surface. Photomed Laser Surg 2010;28:539-45. doi:10.1089/pho.2009.2586.

11. Zogheib L, Bona A, Kimpara E, McCabe J. Effect of hydrofluoric acidetching duration on the roughness and flexural strength of a lithiumdisilicatebased glass ceramic. Braz Dent J 2011;22:45-50.doi:10.1590/S010364402011000100008.

12. Grewal GK, Torrealba Y, Lagrave MO. Orthodontic bonding to porcelain Asystematic review 2014;84. doi:10.2319/083013-636.1.

13. Bertolini JC. Hydrofluoric acid: a review of toxicity. J Emerg Med1992;10:163-8. doi:10.1016/0736-4679(92)90211-b.

14. Litovitz TL, Klein-Schwartz W, Dyer KS, Shannon M, Lee S, Powers M.1997 annual report of the American Association of Poison ControlCenters Toxic Exposure Surveillance System. Am J Emerg Med1998;16:443-97. doi:101016/s0735-6757(98)90000-6.

15. Gallerani M, Bettoli V, Peron L, Manfredini R. Systemic and topical effectsof intradermal hydrofluoric acid. Am J Emerg Med 1998;16:521-2.doi:10.1016/ s0735-6757(98)90008-0. 
16. Özcan M, Allahbeickaraghi A, Dündar M. Possible hazardous effects ofhydrofluoric acid and recommendations for Possible hazardous effects ofhydrofluoric acid and recommendations for treatment approach: $\mathrm{a}$ review2011. doi:10.1007/s00784-011-0636-6.

17. Mirhashemi A, Sharifi N, Moharrami M, Chiniforush N. Evaluation ofDifferent Types of Lasers in Surface Conditioning of Porcelains: A ReviewArticle. J Lasers Med Sci 2017;8:101-11. doi:10.15171/jms.2017.19

18. Sari T, Tuncel I, Usumez A, Gutknecht N. Transmission of Er:YAG laserthrough different dental ceramics. Photomed Laser Surg 2014;32:3741.doi:10.1089/pho.2013.3611.

19. Gökçe B, Özpinar B, Dündar M, Çömlekoglu E, Sen BH, Güngör MA.Bond Strengths of All-Ceramics: Acid vs Laser Etching. Oper Dent2007;32:1738. doi:10.2341/06-52

20. Dilber E, Yavuz T, Kara HB, Ozturk AN. Comparison of the Effects ofSurface Treatments on Roughness of Two Ceramic Systems. PhotomedLaser Surg 2012;30:308-14. doi:10.1089/pho.2011.3153.

21. Kara HB, Dilber E, Koc 0, Ozturk AN, Bulbul M. Effect of different surfacetreatments on roughness of IPS Empress 2 ceramic. Lasers Med Sci2012;27:267-72. doi:10.1007/s10103-010-0860-3.

22. Alakus Sabuncuoglu F, Erturk E. Shear bond strength of brackets bondedto porcelain surface: in vitro study. J Istanbul Univ Fac Dent2016;50:9-18. doi:10.17096/jiufd.95403.

23. Yavuz T, Dilber E, Kara H, Tuncdemir A, Ozturk A. Effects of differentsurface treatments on shear bond strength in two different ceramicsystems. vol. 28. 2012. doi:10.1007/s10103-012-1201-5.

24. Yassaei S, Moradi F, Aghili H, Kamran MHL. Shear bond strength oforthodontic brackets bonded to porcelain following etching with Er:YAGlaser versus hydrofluoric acid. Orthodontics (Chic) 2013;14:e82-7. doi:10.11607/ortho.856.

25. Özdemir H, Aladağ Lì. Effect of different surface treatments on bondstrength of different resin cements to lithium disilicate glass ceramic : anin vitro study 2017;2818. doi:10.1080/13102818.2017.1334589.

26. Kursoglu P, Motro PFK, Yurdaguven H. Shear bond strength of resincement to an acid etched and a laser irradiated ceramic surface. J AdvProsthodont 2013;5:98-103. doi:10.4047/jap.2013.5.2.98.

27. Esmaeel M, Chaharom E, Azar FP, Mohammadi N, Nasiri R. Effect ofSurface Preparation with Nd:YAG and Er,Cr:YSGG Lasers on the RepairBond Strength of Lithium Disilicate Glass Ceramic to a SiloranebasedComposite Resin. Tabriz Univ Med Sci 2018;12:12-7.doi:10.15171/ joddd.2018.003

28. Rossato DM, Bandeca MC, Saade EG, Lizarelli RFZ, Bagnato VS, SaadJRC Influence of Er:YAG laser on surface treatment of aged compositeresin to repair restoration. Laser Phys 2009;19:2144-9. doi:Doi10.1134/ S1054660x09210105.

29. Mirzaie M, Garshasbzadeh NZ, Yassini E, Shahabi S, Chiniforush N.Effect of Laser Treatment on Surface Morphology of Indirect CompositeResin: Scanning Electron Microscope (SEM) Evaluation. J Lasers MedSci 2013:4:92-5.

30. Ahmadizenouz G, Esmaeili B, Taghvaei A, Jamali Z, Jafari T, AmiriDaneshvar $F$, et al. Effect of different surface treatments on the shearbond strength of nanofilled composite repairs. J Dent Res Dent Clin DentProspects 2016;10:9-16. doi:10.15171/joddd.2016.002.

31. Alizadeh Oskoee P, Mohammadi N, Ebrahimi Chaharom ME, Kimyai S,Pournaghi Azar F, Rikhtegaran S, et al. Effect of Surface Treatment withEr;Cr:YSSG, Nd:YAG, and CO2 Lasers on Repair Shear Bond Strengthof a Silorane-based Composite Resin. J Dent Res Dent Clin DentProspects 2013;7:61-6. doi:10.5681/joddd.2013.011.

32. Mirzaei M, Yasini E, Tavakoli A, Chiniforush N. Effect of Different Powersof Er,Cr:YSGG Laser Treatment on Surface Morphology of MicrohybrideComposite Resin: Scanning Electron Microscope (SEM) Evaluation. JLasers Med Sci 2015;6:62-6.

33. Mirzaie M, Yassini E, Etemadi A, Tavakoli A, Chiniforush N. Surfacetreatment comparison by application of diamond bur and Er,Cr:YSGG atdifferent powers: morphological and mechanical evaluation. Laser Ther2016;25:215-20. doi:10.5978/islsm.16-0R-18.

34. Oskoee PA, Oskoee SS, Rikhtegaran S, Pournaghi-Azar F, GholizadehS, Aleyasin $Y$, et al. Effect of various laser surface treatments on repairshear bond strength of aged silorane-based composite. J Lasers Med Sci2017;8:186-90. doi:10.15171/jms.2017.34.

35. Barutcigil K, Kul E, Ozarslan MM, Buyukkaplan US. Effect of DifferentSurface Treatments on Bond Strength of Resin Cement to a CAD / CAMRestorative Material 2016:1-8. doi:10.1111/jopr.12574.

36. Diaci J, Gaspirc B. Comparison of Er:YAG and Er, Cr:YSGG lasers usedin dentistry. J Laser Heal Accademy 2012;2012:1-13.

37. Nagai T, Kawamoto Y, Kakehashi Y, Matsumura H. Adhesive bonding ofa lithium disilicate ceramic material with resin-based luting agents. $J$ OralRehabil 2005;32:598-605. doi:10.1111/j.1365-2842.2005.01464.x.

38. Turkmen C, Durkan M, Cimilli H, Oksuz M. Tensile bond strength ofindirect composites luted with three new self-adhesive resin cements todentin. $J$ Appl Oral Sci 2011;19:363-9. doi:10.1590/s1678-77572011005000011.

39. Vaz RR, Hipolito V Di, D'Alpino PHP, Goes MF de. Bond strength andinterfacial micromorphology of etch-and-rinse and self-adhesive resincements to dentin. J Prosthodont 2012;21:101-11. doi:10.1111/j.1532849X.2011.00794.x.

40. Viotti RG, Kasaz A, Pena CE, Alexandre RS, Arrais CA, Reis AF.Microtensile bond strength of new self-adhesive luting agents andconventional multistep systems. J Prosthet Dent 2009;102:306-12.doi:10.1016/S00223913(09)60180-3.

41. Gale MS, Darvell BW. Thermal cycling procedures for laboratory testingof dental restorations. J Dent 1999;27:89-99.

42. Heintze SD. Systematic reviews: I. The correlation between laboratorytests on marginal quality and bond strength. II. The correlation betweenmarginal quality and clinical outcome. J Adhes Dent 2007;9 Suppl1:77-106.

43. Van Meerbeek B, Peumans M, Poitevin A, Mine A, Van Ende A, Neves A,et al. Relationship between bond-strength tests and clinical outcomes.Dent Mater 2010;26:e100-21. doi:10.1016/j.dental.2009.11.148.

44. Can-Karabulut DC, OzFT, Karabulut B, Batmaz I, Ilk 0. Adhesion toprimary and permanent dentin and a simple model approach. Eur J Dent2009;3:32-41.

45. Casagrande L, Goes MF De, Garcia-godoy F. Bond strength and failurepatterns of adhesive restorations in primary teeth aged in the oralenvironment 2006.

46. Morresi AL, D'Amario M, Capogreco M, Gatto R, Marzo G, D'ArcangeloC, et al. Thermal cycling for restorative materials: does a standardizedprotoco exist in laboratory testing? A literature review. J Mech BehavBiomed Mater 2014:29:295-308. doi:10.1016/j.jmbbm.2013.09.013.

47. Go A, Saygin ZE, Ozdemir AK, Orler OG. Influence of Various LaserSurface Modifications on SBS of Titanium and Zirconium OxideSubstructures Zirkonyum Oksit ve Titanyum Metal Alt Yapıların SBSÜzerine Farklı Lazer Yüzey Uygulamalarının Etkisi Influence of VariousLaser Surface Modifications 2017;38. 
48. OzFD, Canatan S, Bolay S. Effects of surface treatments on the bondstrength of composite resin to hybrid computer-assisteddesign/ manufacturing blocks. J Adhes Sci Technol 2019;33:986-1000.doi:101080 /01694243.2019.1575566.

49. Spitznagel FA, Horvath SD, Guess PC, Blatz MB. Resin bond to indirectcomposite and new ceramic/polymer materials: a review of the literature.J Esthet Restor Dent 2014;26:382-93. doi:10.1111/jerd.12100.

50. Fonseca RG, Haneda IG, Almeida-Junior AA, de Oliveira Abi-Rached F,Adabo GL. Efficacy of air-abrasion technique and additional surfacetreatment at titanium/resin cement interface. J Adhes Dent2012;14:453-9. doi:10.3290/j.jad.a23444.
51. Elsaka SE. Bond strength of novel CAD/CAM restorative materials to self-adhesive resin cement: the effect of surface treatments. J Adhes Dent2014;16:531-40. doi:10.3290/j.jad.a33198.

52. Fuentes MV, Ceballos L, Gonzalez-Lopez S. Bond strength of self-adhesive resin cements to different treated indirect composites. Clin Orallnvestig 2013;17:717-24. doi:10.1007/s00784-012-0752-y.

53. Braga RR, Meira JBC, Boaro LCC, Xavier TA. Adhesion to toothstructure: a critical review of "macro" test methods. Dent Mater2010;26:e38-49. doi:10.1016/j.dental.2009.11.150.

\section{Dr. Shahd T. Mandil}

\section{(Corresponding address)}

Postal Code: 11841. Rehab city, Cairo

Date submitted: 2019 Nov 23

E-mail: shahd090790@miuegypt.edu.eg 